\title{
Pervious concrete made with electric furnace slag (FEA): mechanical and hydraulic properties
}

\section{Concreto permeável de escória de forno elétrico (FEA): propriedades mecânicas e hidráulicas}
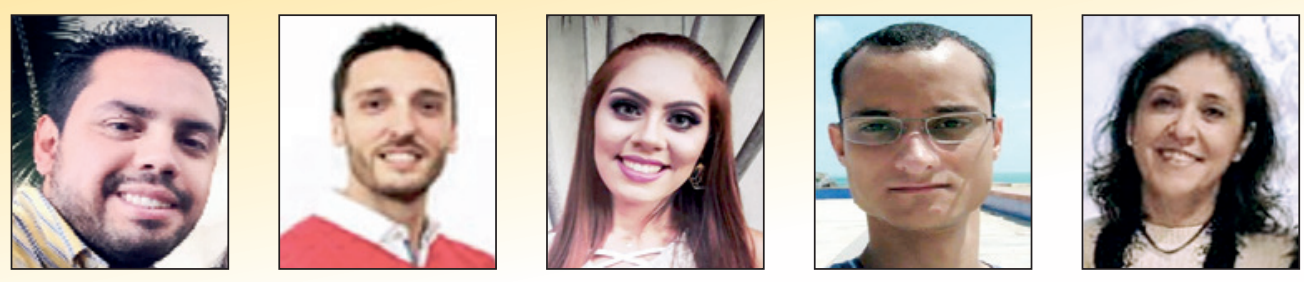

G. F. B. SANDOVAL a gersson.barreto@gmail.com https://orcid.org/0000-0002-8702-8844

I. GALOBARDES isaac.galobardes@xjtlu.edu.cn https://orcid.org/0000-0002-3569-2241

C. DIAS a

caroldias.cdc95@gmail.com https://orcid.org/0000-0001-6604-1313

A. CAMPOS a

andre.moura@uel.br https://orcid.org/0000-0002-0083-4481

B. M. TORALLES a toralles@uel.br

https://orcid.org/0000-0001-8828-7250

\begin{abstract}
The objective of this work is to make feasible the use of FEA slag instead of the conventional bulk aggregate in the pervious concrete (PC) production, reaching the minimum parameters required by NBR16416/2015 and ACI 522R-10. This substitution would minimize the use of natural aggregates, besides taking advantage of a residue that has no specific destination. In order to reach the objective, three FEAs with different grain sizes were chosen: 6-10 mm (A), 10-20 mm (B) and finally a mixture of the two previous ones (C) in the proportion 30-70 respectively. In order to evaluate its mechanical behavior, tests of compressive strength and flexural tensile tests were carried out, while the evaluation of the hydraulic behavior, porosity and constant head permeability test were performed. The compressive strength varies from 19-31MPa and 3-4MPa for flexural tensile strength was obtained. In hydraulic terms, the porosity varied from $15-20 \%$ and the permeability coefficient was $10-12 \mathrm{~mm} / \mathrm{s}$. There is also a direct influence of grains of size less than $4.8 \mathrm{~mm}$ (small aggregate) on the compressive strength and permeability of PCs. At the end of the results, it was possible to establish a correlation between the compressive strength, the permeability and the percentage of grains inferior to $4.8 \mathrm{~mm}$ (sand\%), being this positive in relation to the studied variables, that is, the mechanical and hydraulics. Therefore, it has been concluded that the total substitution of conventional aggregates by FEA in CoPe manufacturing will comply with the minimum parameters of NBR $16416 / 2015$.
\end{abstract}

Keywords: pervious concrete, permeability, porosity, sustainability, electric furnace slag.

\section{Resumo}

O objetivo deste trabalho é viabilizar o uso de escória de forno elétrico (FEA) em substituição ao agregado graúdo convencional na fabricação de concreto permeável (CoPe), atingindo os parâmetros mínimos exigidos pela norma NBR16416/2015. Esta substituição minimizaria a utilização de agregados naturais, além de aproveitar um resíduo que não tem destinação específica. Para alcançar o objetivo foram escolhidos três FEA's com diferentes distribuições granulométricas: 6-10 mm (A), 10-20 mm (B) e finalmente uma mistura das duas anteriores (C) na proporção 30-70 respectivamente. Para avaliar seu comportamento mecânico foram realizados ensaios de resistência à compressão e tração na flexão, enquanto na avaliação do comportamento hidráulico, índice de vazios e permeabilidade à carga constante foram realizados. Na compressão foram obtidas resistências variando de 19-31MPa e 3-4MPa na tração na flexão. Em termos hidráulicos, o índice de vazios variou de $15 \%-20 \%$ e o coeficiente de permeabilidade de $10-12 \mathrm{~mm} / \mathrm{s}$. Também se verifica a influência direta dos grãos de tamanho inferior a $4.8 \mathrm{~mm}$ (agregado miúdo) na resistência à compressão e na permeabilidade dos CoPes. Ao final, a partir dos resultados obtidos foi possível estabelecer uma correlação entre a resistência à compressão, a permeabilidade e a porcentagem de grãos inferiores a 4.8mm (\%areia), sendo esta positiva em relação às variáveis estudadas, ou seja, as propriedades mecânicas e hidráulica. Por tanto foi concluído que é viável a substituição total dos agregados convencionais por FEA na fabricação de CoPe cumprindo com os parâmetros mínimos da NBR 16416/2015.

Palavras-chave: concreto permeável, permeabilidade, índice de vazios, sustentabilidade, escória de forno elétrico. 


\section{Introduction}

The growth of the cities has taken place rapidly and sharply in the last years, bringing with it several damages to the environment, including the reduction of pervious areas. Soil waterproofing significantly reduces its natural capacity to absorb rainwater, which can result in floods that mainly affect large urban centers [1, 2]. In civil construction, a widely used material in pavements is conventional concrete, which has a low permeability coefficient (about $1 \times 10-8 \mathrm{~m} / \mathrm{s}$ ) due to its low percentage of voids [3]. For this reason, its application results in soil waterproofing. In search of an alternative that does not waterproof the soil, research has been carried out in the search for materials that allow the passage of water through its structure, without changing the mechanical properties [1].

The use of permeable materials helps to reduce the impacts caused by waterproofing, which provides balance in the hydrological cycle that is altered in a radical way with the waterproof coatings of the big cities, minimizing the risk of accidents with vehicles by the phenomenon of hydroplaning and diseases derived from floods, ensuring the safety of the environment [1].

Among these materials is the pervious concrete (PC) which, because of its composition, has a high porosity due to the partial or total lack of small aggregates in the mixture. This concrete has a drainage capacity greater than the conventional one, which reduces the flow of rainwater present in the surface runoff [4].

PC is composed of Portland cement, coarse aggregate and water, with little or no small aggregate (sand), which facilitates the formation of interconnected internal voids that allow the fast and safe flow of water $[1,2,5,6]$.

In terms of mechanical strength, this material works in the range of 3-30 MPa [7-10], and can be used on pedestrian sidewalks and light traffic pavements. In hydraulic terms, the permeability coefficient of the material varies from 1 to $20 \mathrm{~mm} / \mathrm{s}$, which guarantees the rapid flow of water through its structure [4,11-14].

Currently, construction waste has been used as an aggregate in the manufacture of PC. The mechanical properties obtained with some of these aggregates vary from 6 to $14 \mathrm{MPa}$ in the compressive strength and from 1 to 2 in the flexural strength[15,16], with a reduction in these properties when compared to the use of conventional aggregates [1]. However, the hydraulic properties comply with the requirements of national and international regulations, above $1 \mathrm{~mm} / \mathrm{s}$ [17].

In order to improve the mechanical properties of the pervious concrete made from waste, the steel slag (FEA), which is generated in the production of second-line steel, has been used, and has physical characteristics similar to conventional aggregates [18]. The use of this slag is feasible since according to the Brazilian Steel Institute [19], in the production of one ton of steel, approximately $600 \mathrm{~kg}$ of waste is generated, of which $60 \%$ correspond to steel slag.

When compared to conventional aggregates, aggregates of slag present higher specific mass and negligible amount of fines in the particle size composition [18].

In mechanical terms, pervious concretes with FEA reach compressive strengths in the range of 8-20MPa and flexural strengths of 2 to $4 \mathrm{MPa}$ $[18,20]$, being remarkable the improvement in the mechanical properties. In the hydraulic properties, the material has a porosity in the range of $15-30 \%$ and a permeability coefficient of more than $1 \mathrm{~mm} / \mathrm{s}$.

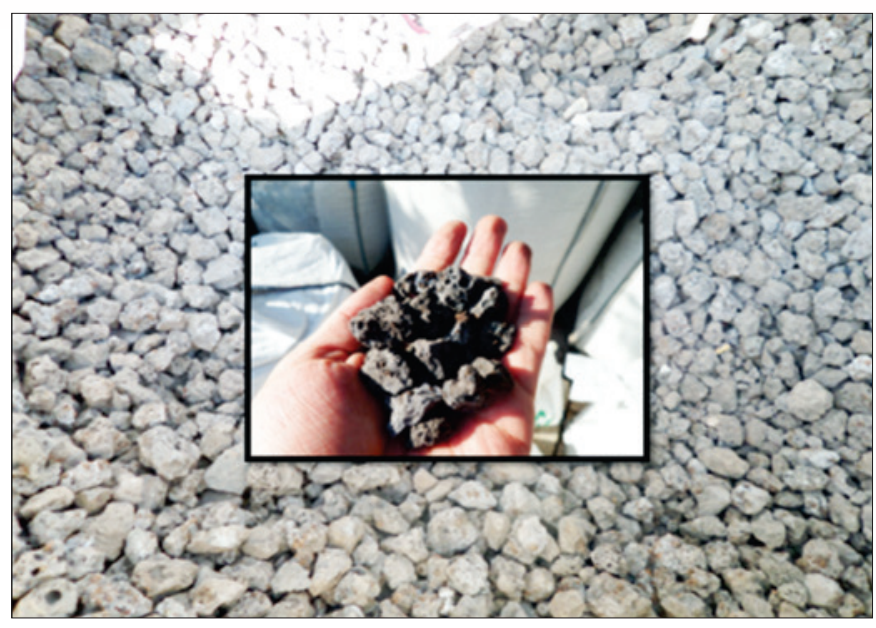

\section{Figure 1}

Steel aggregates used (FEA)

From the above, a study was carried out at the Polytechnic University of Catalonia on pervious concrete with stabilized FEA. Therefore, this study evaluated the feasibility of using FEA as large aggregates in the manufacture of $\mathrm{PC}$ with minimum mechanical and hydraulic performance required by ABNT NBR 16416/2015. For this, three pervious concretes were produced with three different slag particle size, and evaluated for mechanical strengths (compression and flexural) and hydraulic properties (porosity and permeability).

\section{Material and methods}

\subsection{Material}

In order to evaluate the mechanical and hydraulic properties of PC produced with steel slag aggregates (Figure 1), three different particle sizes were chosen: the first with aggregates of size ranging from 4 to $10 \mathrm{~mm}(\mathrm{~A})$, the second with size of $10-20 \mathrm{~mm}(B)$ and the third corresponding to a particle size composition of $30 \%(A)$ and $70 \%(B)$, generating the particle size $(C)$. The slag used is stabilized with an expansion potential of 0.6 being practically negligible and can be used in the manufacture of building materials according to UNE-EN 1744-1:2010 [21].

In Figure 2 and Table 1, the particle size curves and the particle

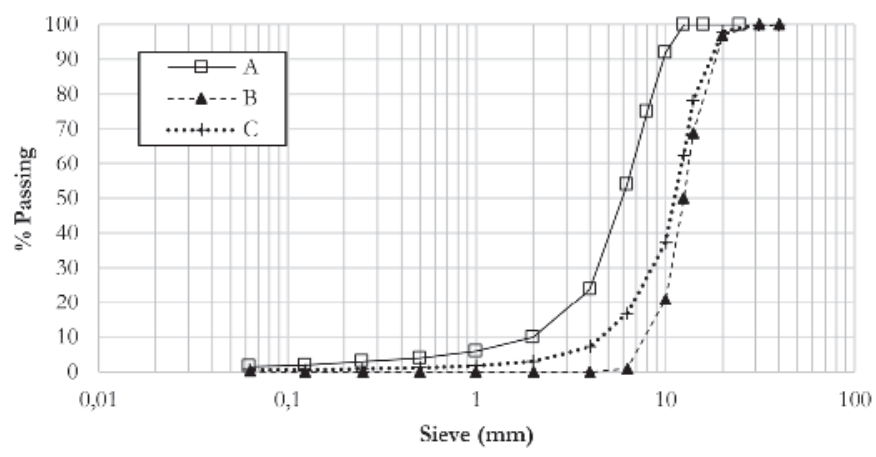

Figure 2

Particle size of steel slag aggregates 
Pervious concrete made with electric furnace slag (FEA): mechanical and hydraulic properties

Table 1

Particle size analysis of steel aggregates

\begin{tabular}{|c|c|c|c|c|c|}
\hline \multicolumn{2}{|c|}{ A } & \multicolumn{2}{|c|}{ B } & \multicolumn{2}{|c|}{ C } \\
\hline Sieve $(\mathrm{mm})$ & \% passing & Sieve $(\mathrm{mm})$ & \% passing & Sieve $(\mathrm{mm})$ & \% passing \\
\hline 40 & 100 & 40 & 100 & 40 & 100 \\
\hline 25 & 100 & 31.5 & 100 & 31.5 & 100 \\
\hline 16 & 100 & 20 & 97 & 20 & 97.9 \\
\hline 12.5 & 100 & 14 & 69 & 14 & 78.3 \\
\hline 10 & 92 & 12.5 & 50 & 12.5 & 62.6 \\
\hline 8 & 75 & 10 & 21 & 10 & 37.2 \\
\hline 6.3 & 54 & 6.3 & 1 & 6.3 & 16.9 \\
\hline 4 & 24 & 4 & 0 & 4 & 7.2 \\
\hline 2 & 10 & 2 & 0 & 2 & 3 \\
\hline 1 & 6 & 1 & 0 & 1 & 1.8 \\
\hline 0.5 & 4 & 0.5 & 0 & 0.5 & 1.2 \\
\hline 0.25 & 3 & 0.25 & 0 & 0.25 & 0.9 \\
\hline 0.125 & 2 & 0.125 & 0 & 0.125 & 0.6 \\
\hline 0.063 & 1.6 & 0.063 & 0.2 & 0.063 & 0.62 \\
\hline Sand (\%) & 50.6 & \multicolumn{2}{|c|}{1.2} & \multicolumn{2}{|c|}{15.32} \\
\hline $\operatorname{Dmax}(\mathrm{mm})$ & 10 & \multicolumn{2}{|c|}{20} & \multicolumn{2}{|c|}{20} \\
\hline
\end{tabular}
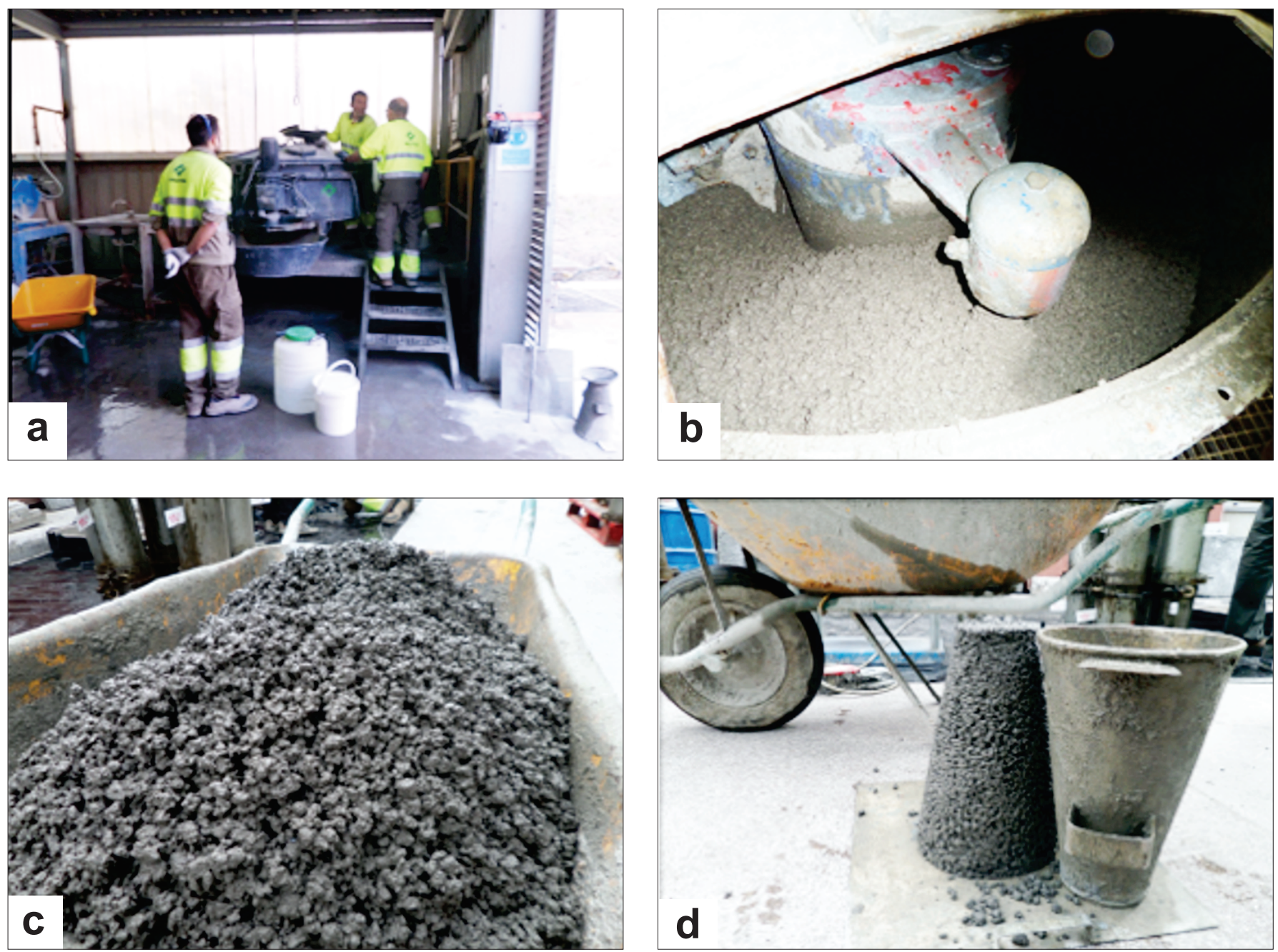

\section{Figure 3}

Method for production of pervious concretes: a) mixing in the concrete mixer; b) visual analysis;

c) final result; d) slump test 


\section{Table 2}

Experimental planning

\begin{tabular}{cccccc}
\hline \multirow{2}{*}{$\begin{array}{c}\text { Type } \\
\text { of test }\end{array}$} & \multirow{2}{*}{ Test } & Type of & Specimen size & \multicolumn{2}{c}{ Samples per age } \\
\cline { 3 - 6 } specimen & (mm) & 7 days & $\mathbf{1 4}$ days & $\mathbf{2 8}$ days \\
\hline \multirow{2}{*}{ Mechanical } & Compressive strength (NBR 5739/1994) & Cylindrical & $150 \times 300$ & 5 & - \\
& Flexural tensile strength (ASTM C78-02) & Beam & $150 \times 150 \times 600$ & - & - \\
\hline \multirow{2}{*}{ Hydraulic } & Porosity (Empirical) & Cylindrical & $150 \times 300$ & - & - \\
& Constant head permeability & Cylindrical & $150 \times 300$ & - & - \\
\hline
\end{tabular}

size analysis of the slag aggregates used are shown, where it is possible to observe that the slag A shows a more continuous trend, whereas the slag $B$ and $C$ have uniform grain sizes.

To analyze the influence of the fines on the mechanical and hydraulic behavior of the material, the material passing through the sieves 4.8 up to $0.063 \mathrm{~mm}$ was considered as small aggregate (sand), as listed in Table 1. The steel aggregates used in the experimental study had different particle size curves, and therefore different sand contents. Slag A presents a percentage of sand of $50.6 \%, \mathrm{~B}, 1.2 \%$ and the slag $\mathrm{C}, 15.32 \%$.

\subsection{Mixing and production}

Concretes were produced in a vertical shaft mixer of PROMSA (Barcelona, Spain), with the following mixing procedure: first, the steel aggregates, the sand (according to each trait), the cement and $50 \%$ of the water were added; these were mixed for 1 minute for homogenization. Then, the resin was added and the material was mixed for a further 1 minute, and finally the remainder of the water was added along with the additive, mixing for 3 minutes, totaling 5 minutes mixing. Figure 3 illustrates the steps of the mixing process of the pervious concretes.

During the production of the three mixtures, it was verified that none of them presented excess water and that all reached zero slump, as expected according to the literature for this type of concrete, due to the low a/c ratios [1,2]. In Figure 3 (c), the plasticity of the mixture is observed, whereas in Figure 3 (d) the slump test is shown, which was zero for the 3 particle sizes.
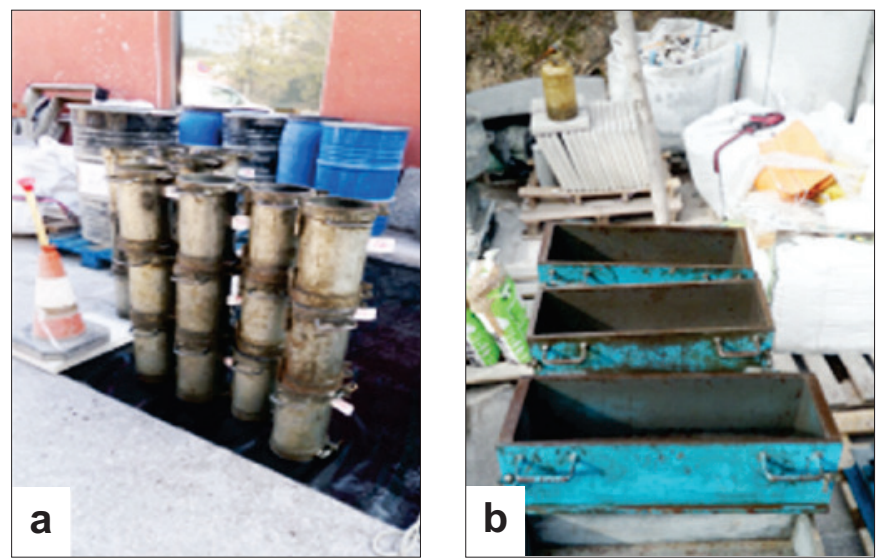

\subsection{Experimental planning}

After the mixing process, the specimens were cast for the mechanical and hydraulic tests, respectively. Experimental planning is presented in Table 2.

As presented in Table 2, the tests of compressive strength, porosity and permeability were performed on cylindrical specimens in order to directly correlate these three properties.

\subsection{Compaction}

The compacting procedure used in the cylindrical and prismatic specimens was the single-layer vibrating table (Figure 4c) for 30 seconds. Cylindrical specimens were cast with $150 \mathrm{~mm}$ in diameter and $300 \mathrm{~mm}$ in height (Figure 4a and 4d), as well as beams with $150 \mathrm{~mm} \times 150 \mathrm{~mm}$ $x 600 \mathrm{~mm}$ (Figure $4 \mathrm{~b}$ and $4 \mathrm{~d}$ ). Table 3 lists the consumption of materials per cubic meter, used in the production of pervious concrete.

As the a/c ratio employed was very low, it was necessary to incorporate the polyfunctional superplasticizer additive $(\mathrm{pH} 5$, density $1,180 \mathrm{~g} / \mathrm{cm}^{3}$ and chloride contents $<0.1 \%$ ) [22], which ensured good plasticity in the mixing and facilitated the casting process of specimens. It was also used a polymer resin ( $\mathrm{pH}$ 9, density $1.05 \mathrm{~g} /$ $\mathrm{cm}^{3}$, viscosity of 12cPoises) [23] in order to increase the adhesion between the mortar and the steel aggregates, thus guaranteeing good mechanical strength without damaging the permeability.

\subsection{Porosity}

The porosity in the hardened state was determined in the same
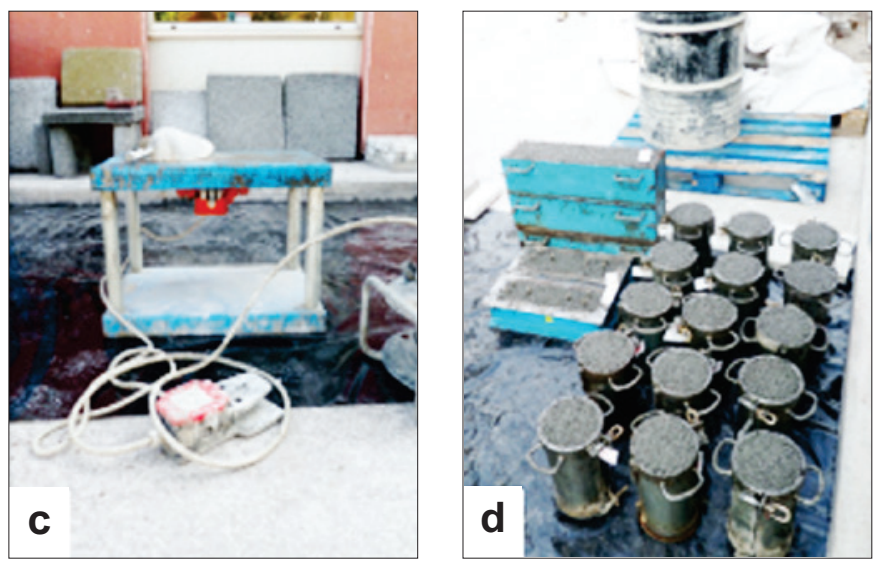

Figure 4

Casting and compacting specimens 
Table 3

Consumption of materials per $\mathrm{m}^{3}$

\begin{tabular}{ccccccc}
\hline Particle size & $\begin{array}{c}\text { Cement } \\
\left(\mathrm{kg} / \mathrm{m}^{3}\right)\end{array}$ & $\begin{array}{c}\text { Slag } \\
\left(\mathrm{kg} / \mathrm{m}^{3}\right)\end{array}$ & $\mathrm{a} / \mathrm{c}$ & $\begin{array}{c}\text { Water } \\
\left(\mathrm{kg} / \mathrm{m}^{3}\right)\end{array}$ & $\begin{array}{c}\text { Polymer resin } \\
\left(\mathrm{kg} / \mathrm{m}^{3}\right)\end{array}$ & $\begin{array}{c}\text { Superplasticizer } \\
\left(\mathrm{kg} / \mathrm{m}^{3}\right)\end{array}$ \\
\hline A & 350 & 2570 & 0.24 & 142.8 & 50 & 1.05 \\
B & 350 & 2570 & 0.24 & 142.8 & 50 & 1.05 \\
C & 350 & $771-1779$ & 0.24 & 14.8 & 50 & 1.05 \\
\hline
\end{tabular}

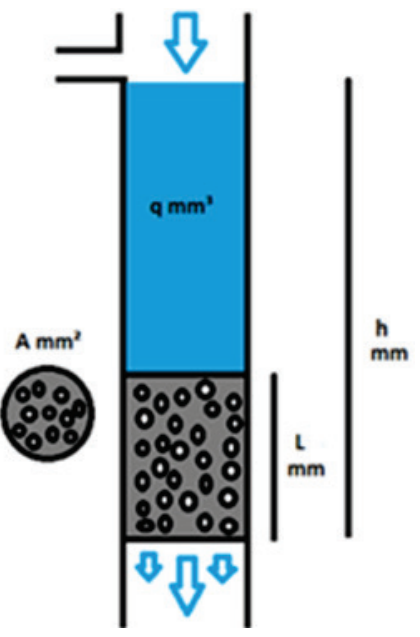

Figure 5

Constant head permeability test

test specimens used in the compressive strength test, which were tested in the saturated surface dry condition, in order to guarantee the non-absorption of water. The specimens were wrapped in PVC film by the side and bottom surfaces and then inserted in the cylindrical metal mold of the same dimensions to ensure that the PVC film did not suffer deformations. The metal mold with the specimen had its mass measured and tared on a scale. Finally, water was added to fill the internal voids of the material and when the water touched the surface of the specimen, its mass was determined. The porosity was calculated using Equation $1[4,13,24]$.

$V=\frac{V_{\text {water }} * 100}{V_{c p}}$

Where:

$\mathrm{V}=$ porosity $(\%)$

$\mathrm{V}_{\text {water }}=$ Volume of water added up until reaching the surface of the specimen (I)

$\mathrm{V}_{\mathrm{cp}}=$ Volume of the specimen with $150 \mathrm{~mm}$ in diameter and 300 $\mathrm{mm}$ in height (I)

\subsection{Permeability}

The constant head permeability test follows the principle of Darcy's Law [13,25-27] and basically measures the amount of water passing through the specimen over a given time interval. For this test, the specimens used in the compressive strength test were again used, also in the saturated surface dry condition. The specimens were wrapped in PVC film, followed by a coating with conventional adhesive tape and, finally, a layer of polyethylene adhesive tape with cotton cloth (Silver Tape), in order to guarantee impermeability [4].

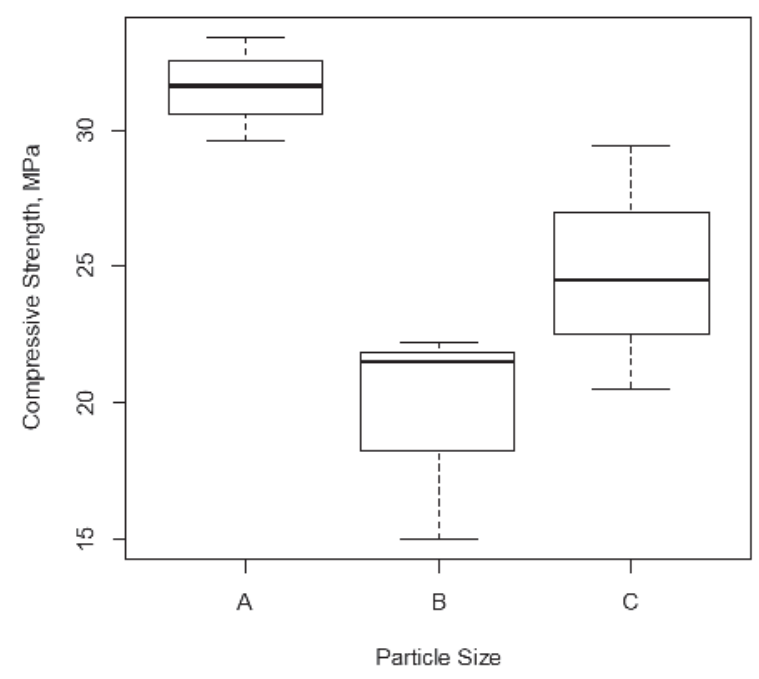

a)

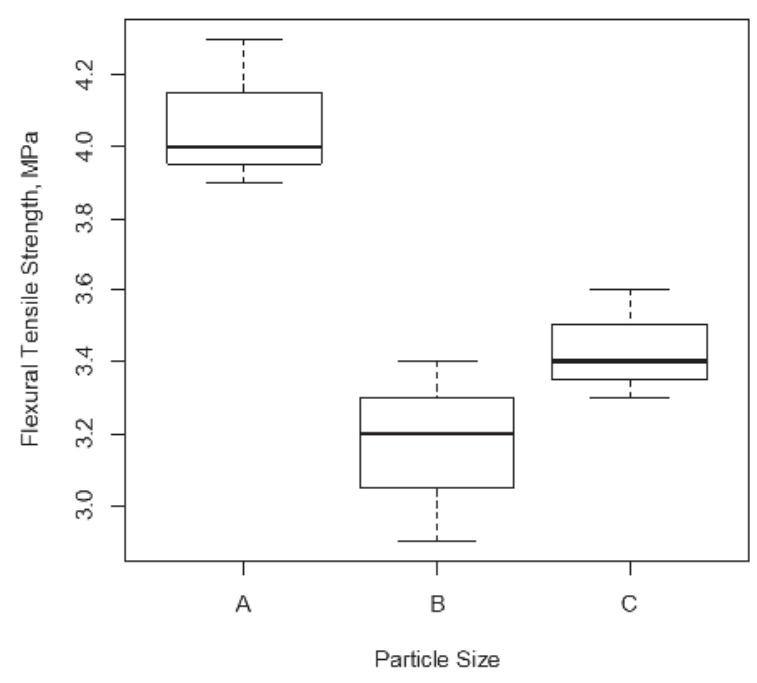

b)

Figure 6

Results of mechanical properties a) Compressive strength; b) Flexural tensile strength 
The specimen was then positioned between two PVC tubes of the same diameter, the top tube containing an outflow pipe to ensure constant water level during the test, as shown in Figure 5.

\section{Results and analysis}

\subsection{Mechanical properties}

The results corresponding to the compressive strength and flexural strength tests are shown in Figure 6.

For the compressive strength, ANOVA indicated with a $p$-value lower than $0.5 \%$ that particle size $A$ is significantly different from the other two particle sizes used in the two mechanical properties analyzed, presenting on average a strength value of approximately $32 \mathrm{MPa}$ in the compression. This result can be explained by the arrangement of the granulometry A, aggregates which have a larger size range, increasing the points of contact between the particles, which facilitates the distribution of stresses and results in an increased mechanical strength. However, the particle sizes $B$ and $C$ do not present significant differences from each other. In the case of concrete with aggregates of the slag $B$, its particle size is more uniform and the contact between the grains is punctual, which impairs the distribution of the loads and decreases the strength. Finally, the slag $\mathrm{C}$ improves mechanical strength, but because it presents a predominance of size $10-20 \mathrm{~mm}$, it is lower compared to A. In the case of flexural tensile strength, the tendency was practically equal, with particle size A presenting a significant difference from the other two, $B$ and $C$, which showed no difference from each other. The three particle sizes comply with the minimum strength established by the Brazilian standard NBR 16416/2015 (> 2MPa), to be used in light traffic pavements or sidewalks for pedestrians.

\subsection{Hydraulic properties}

The results corresponding to the porosity and permeability are

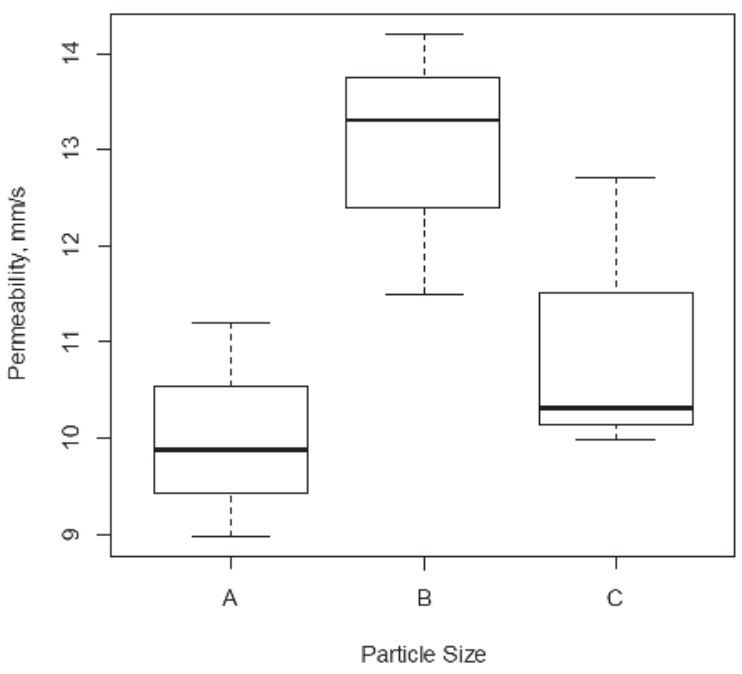

a) shown in Figure 7. As shown in Figure 7, the three slag particle sizes used complied with the minimum permeability required by NBR $16416 / 2015$, of $1 \mathrm{~mm} / \mathrm{s}$. With a value lower than $0.5 \%$, the particle size A presented significant difference only from the particle size $B$, and the particle sizes $B$ and $C$ showed no difference from each other. The permeability coefficients obtained are between 10 and 12 $\mathrm{mm} / \mathrm{s}$, within the range of values reported in the literature [28-30] the impact of this distribution on the permeability of the pavement has not been considered. This research investigates the impact of a vertical porosity distribution on the overall permeability of pervious concrete. First, an unimpaired porosity-permeability relationship was generated using pervious concrete specimens which had uniform porosity throughout. This relationship was then used in conjunction with the vertical porosity distribution of surface compacted pervious concrete specimens to generate a vertical permeability distribution. An effective permeability value was used to summarize the overall behavior of the permeability distribution and was shown to have a much better correlation with the actual permeability of the specimens than the permeability predicted using the average porosity of the specimen. Additionally, an analysis of the relationship between the permeability distribution and the effective permeability showed that the minimum permeability (and therefore minimum porosity. The permeability of the material is related to the particle size distribution of the grains, which indicates that more continuous particle sizes exhibits lower permeability coefficients when compared to uniform particle sizes, as is the case of slags A and B [4].

Regarding the porosity, the 3 particle sizes present a significant difference from each other, as observed in Figure 7, and the values obtained are between 15 and $20 \%$. This property is directly related to the particle size distribution and the consumption of materials.

\subsection{Correlations}

Table 4 lists a summary of the mechanical and hydraulic properties

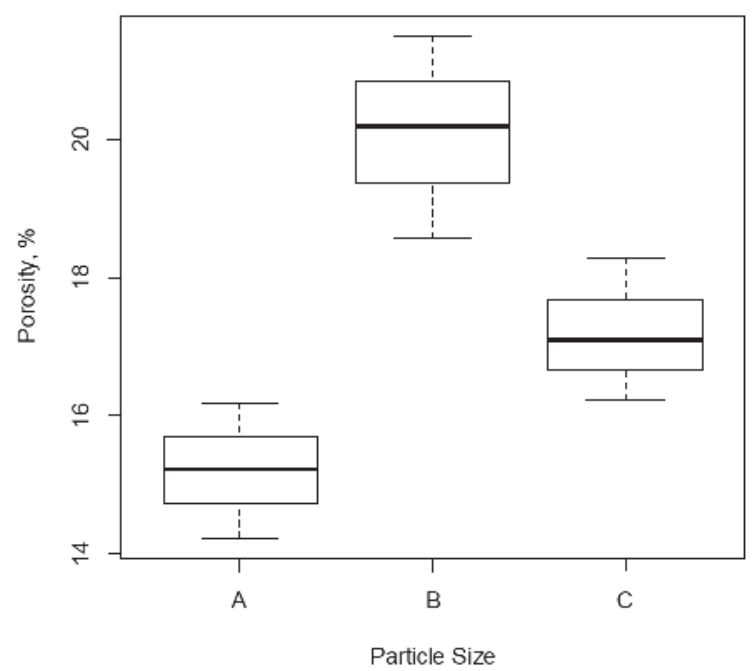

b)

Figure 7

Results of hydraulic properties a) Permeability; b) Porosity 
Table 4

Summary of results

\begin{tabular}{|c|c|c|c|c|c|c|c|c|c|c|c|c|}
\hline \multirow{2}{*}{$\begin{array}{c}\text { Particle size } \\
\text { Property }\end{array}$} & \multicolumn{4}{|c|}{ A } & \multicolumn{4}{|c|}{ B } & \multicolumn{4}{|c|}{ C } \\
\hline & $\begin{array}{c}f^{\prime} c \\
(M P a)\end{array}$ & $f_{f f}(M P a)$ & $\begin{array}{c}\Phi \\
(\%)\end{array}$ & $\begin{array}{c}\mathrm{k} \\
(\mathrm{mm} / \mathrm{s})\end{array}$ & $\begin{array}{c}f^{\prime} c \\
(M P a)\end{array}$ & $\begin{array}{c}f_{\text {ft }} \\
(\mathrm{MPa})\end{array}$ & $\begin{array}{c}\Phi \\
(\%)\end{array}$ & $\begin{array}{c}\mathrm{k} \\
(\mathrm{mm} / \mathrm{s})\end{array}$ & $\begin{array}{c}f^{\prime} c \\
(M P a)\end{array}$ & $f_{f f}(M P a)$ & $\begin{array}{c}\mathrm{k} \\
(\mathrm{mm} / \mathrm{s})\end{array}$ & $\begin{array}{c}\Phi \\
(\%)\end{array}$ \\
\hline Mean & 31.53 & 4.07 & 15.23 & 10.02 & 18.90 & 3.17 & 20.09 & 12.97 & 23.30 & 3.43 & 11.00 & 17.21 \\
\hline SD & 1.29 & 0.16 & 0.66 & 0.78 & 2.60 & 0.18 & 1.02 & 0.98 & 1.87 & 0.11 & 1.13 & 0.72 \\
\hline CV (\%) & 4.09 & 3.83 & 4.32 & 7.83 & 13.76 & 5.61 & 5.07 & 7.54 & 8.01 & 3.24 & 10.30 & 4.21 \\
\hline
\end{tabular}

of pervious concrete obtained in the experimental study, as well as the mean values, standard deviation and coefficient of variation of each property.

According to Table 4, the coefficients of variation found for the properties evaluated are in accordance with the literature [31] due to the quality control during the casting of the specimens, once all concretes were cast on the same day, reducing the temperature interference. In addition, moisture control of the aggregates was performed and, because the compacting procedure was performed with the help of the vibrating table, there was a reduction in the variability resulting from the human operator in the production process.

In order to better interpret the obtained results, two parametric correlation analyses were implemented: the first related to the hydraulic properties (porosity and permeability), and the second related to the influence of fine aggregates (\% sand) corresponding to each particle size studied in the mechanical and hydraulic properties of the material.

Figure 8 illustrates the proposed correlation between the porosity and the permeability coefficient of the pervious concrete.

According to some studies, the correlation between permeability and the porosity for large intervals and large number of data have a most exponential trend $[13,28]$ the impact of this distribution on the permeability of the pavement has not been considered. This research investigates the impact of a vertical porosity distribution on the overall permeability of pervious concrete. First, an unimpaired porosity-permeability relationship was generated using pervious concrete specimens which had uniform porosity throughout. This relationship was then used in conjunction with the vertical porosity distribution of surface compacted pervious concrete specimens to generate a vertical permeability distribution. An effective permeability value was used to summarize the overall behavior of the permeability distribution and was shown to have a much better correlation with the actual permeability of the specimens than the permeability predicted using the average porosity of the specimen. Additionally, an analysis of the relationship between the permeability distribution and the effective permeability showed that the minimum permeability (and therefore minimum porosity, but when smaller intervals are considered and if there is little data, it can be considered a linear trend [1,32-34], which is the case of the present study, therefore a linear correlation was proposed considering a porosity of approximately $15-20 \%$ and a permeability range of $9-14 \mathrm{~mm} / \mathrm{s}$, this correlation presented a good fit for the studied materials.

Considering that the 3 slags used had different sand contents $(<4.8$ $\mathrm{mm}$ ), an analysis was carried out to check for the influence of this percentage of sand on the mechanical and hydraulic properties of the material. Figure 9 shows the proposed correlation between the properties of compressive strength and permeability with the percentage of sand of each of the particle sizes used.

According to Figure 9, there is an approximate linear correlation between the compressive strength and the percentage of sand for the analyzed data range, i.e., the higher the amount of sand, the greater the strength of the material, since sizes smaller than 4.8 $\mathrm{mm}$ improve the particle size curve, reducing porosity and increasing the mechanical response of the material. On the other hand, the increase in sand percentage results in a decrease in the permeability of the material, since this results in the formation of smaller voids, reducing the hydraulic capacity of the internal channels of the concrete and consequently, the speed of water passage.

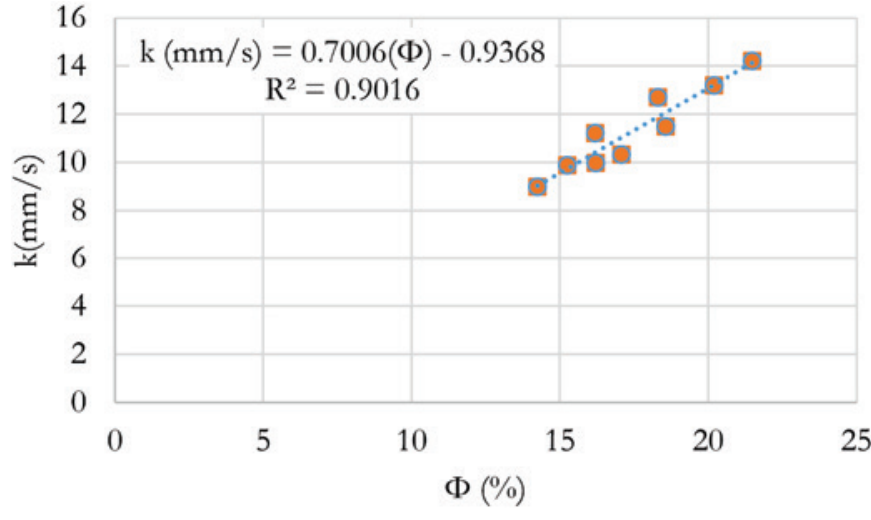

Figure 8

Correlation between permeability and porosity

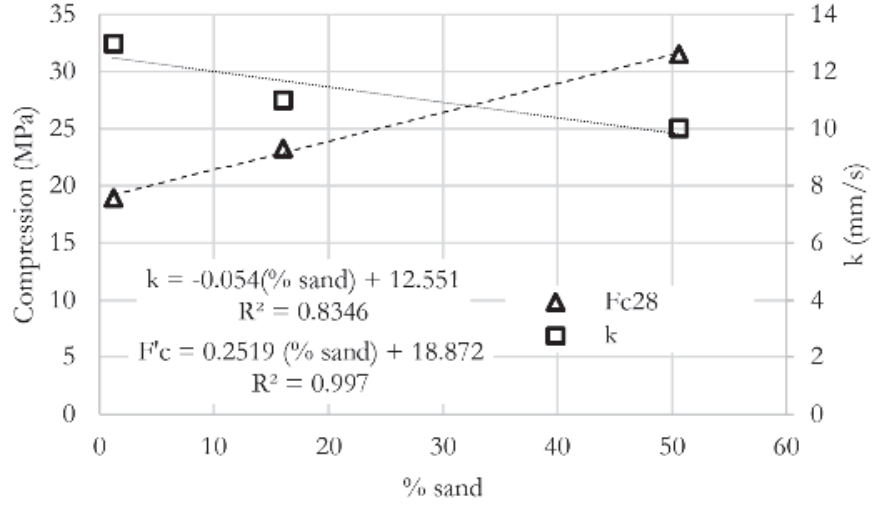

Figure 9

Correlation between $\mathrm{F}^{\prime} \mathrm{c}$ and $\mathrm{k} v \mathrm{~s} \%$ sand 
Table 5

Experimental results

\begin{tabular}{cccc}
\hline PC & $\begin{array}{c}\mathbf{f}^{\prime} \\
(\mathbf{M P a})\end{array}$ & $\begin{array}{c}\mathbf{k} \\
(\mathbf{m m} / \mathbf{s})\end{array}$ & $\begin{array}{c}\text { sand } \\
(\%)\end{array}$ \\
\hline A & 31.50 & 10.02 & 50.60 \\
B & 18.90 & 12.97 & 1.20 \\
C & 23.30 & 11.00 & 16.02 \\
\hline
\end{tabular}

Thus, there is a balance between the percentage of sand and the two properties previously analyzed, which means that depending on the final use of the material, the addition of grains smaller than $4.8 \mathrm{~mm}$ can be implemented or not to increase the mechanical strength without highly compromising the permeability of the material.

In order to evaluate the possible relationships between the experimental results obtained, the results of compressive strength ( $\left.f^{\prime} \mathrm{c}\right)$, permeability $(k)$ and percentage of sand $(s)$ were collected for each mixture studied. These data can be found in Table 5.

To study the relationships between parameters, a three-step analysis $(1,2,3)$ was performed. The results of the three characteristics are used to obtain an equation that relates them through a nonlinear regression (Equation 2) using the experimental software for data curve fit (LAB Fit).

${f^{\prime}}^{\prime}=19.274 \cdot k^{0.004 \cdot(\% \text { sand })}$

Considering the coefficient of correlation obtained, the estimates are well suited, since $R^{2}$ is equal to 0.98 . The average relative error of the estimate of f'c presents a value of $2.07 \%$, which cannot be considered significant in relation to the intrinsic variability presented by the previous concrete. Thus, using this approach, an acceptable correlation was obtained for the range of data analyzed (empirical analysis).

\section{Conclusions}

According to the results obtained in the present study, the following conclusions were obtained:

- The three slag particle sizes used meet the minimum parameters required by NBR $16416 / 2015$, easily complying with the permeability and strength values, enabling the use of this type of aggregates in the manufacture of pedestrian walkways and light traffic pavements;

- The maximum size of the slag grains was predominant for the compressive strength. In the case of the range $6-10 \mathrm{~mm}$, the best result was obtained, mainly due to its particle size composition with $50.6 \%$ sand, which led to a greater gain in strength;

- In hydraulic terms, the correlation between the permeability and the porosity of the material agrees with that found in the literature for pervious concretes with a porosity between 15 and $25 \%$, since they are directly proportional properties and are related to the particle size of the type of aggregate used;

- There is a direct influence of the sand percentage relative to each particle size on the mechanical and hydraulic properties of $\mathrm{PC}$, so an optimum range of sand can be found which contributes to the strength without compromising the permeability of the material.

\section{References}

[1] G.F. Barreto Sandoval, DESEMPENHO DO CONCRETO POROSO COM, Universidade Estadual de Londrina, 2014. http://www.uel.br/pos/enges/portal/pages/arquivos/dissertacao/GERSSON BARRETO SANDOVAL 2013-1.pdf.

[2] P.D. Tennis, M.L. Leming, D.J. Akers, Pervious Concrete Pavements, 2004. http://myscmap.sc.gov/marine/NERR/ pdf/PerviousConcrete_pavements.pdf.

[3] P.K. Mehta, P.J.M. Monteiro, Concrete: microstructure, properties, and materials, 2006. doi:10.1036/0071462899.

[4] G.F.B. Sandoval, I. Galobardes, R.S. Teixeira, B.M. Toralles, Comparison between the falling head and the constant head permeability tests to assess the permeability coefficient of sustainable Pervious Concretes, Case Stud. Constr. Mater. 7 (2017) 317-328. doi:10.1016/j.cscm.2017.09.001.

[5] P. Chindaprasirt, S. Hatanaka, T. Chareerat, N. Mishima, Y. Yuasa, Cement paste characteristics and porous concrete properties, Constr. Build. Mater. 22 (2008) 894-901. doi:10.1016/j.conbuildmat.2006.12.007.

[6] A.K. Chandrappa, K.P. Biligiri, Pervious concrete as a sustainable pavement material-Research findings and future prospects: A state-of-the-art review, Constr. Build. Mater. 111 (2016) 262-274. doi:10.1016/j.conbuildmat.2016.02.054.

[7] O. Deo, N. Neithalath, Compressive behavior of pervious concretes and a quantification of the influence of random pore structure features, Mater. Sci. Eng. A. 528 (2010) 402412. doi:10.1016/j.msea.2010.09.024.

[8] R. Zhong, K. Wille, Compression response of normal and high strength pervious concrete, Constr. Build. Mater. 109 (2016) 177-187. doi:10.1016/j.conbuildmat.2016.01.051.

[9] O. Deo, N. Neithalath, Compressive response of pervious concretes proportioned for desired porosities, Constr. Build. Mater. 25 (2011) 4181-4189. doi:10.1016/j.conbuildmat.2011.04.055.

[10] R. Zhong, K. Wille, Linking pore system characteristics to the compressive behavior of pervious concrete, Cem. Concr. Compos. 70 (2016) 130-138. doi:10.1016/j.cemconcomp.2016.03.016.

[11] B. Huang, H. Wu, X. Shu, E.G. Burdette, Laboratory evaluation of permeability and strength of polymer-modified pervious concrete, Constr. Build. Mater. 24 (2010) 818-823. doi:10.1016/j.conbuildmat.2009.10.025.

[12] J.T. Kevern, Evaluating Permeability and Infiltration Requirements for Pervious Concrete, J. Test. Eval. 43 (2015) 20130180. doi:10.1520/JTE20130180.

[13] N. Neithalath, M.S. Sumanasooriya, O. Deo, Characterizing pore volume, sizes, and connectivity in pervious concretes for permeability prediction, Mater. Charact. 61 (2010) 802813. doi:10.1016/j.matchar.2010.05.004.

[14] H. Li, M. Kayhanian, J.T. Harvey, Comparative field permeability measurement of permeable pavements using ASTM C1701 and NCAT permeameter methods, J. Environ. Manage. 118 (2013) 144-152. doi:10.1016/j.jenvman.2013.01.016.

[15] M. Aamer Rafique Bhutta, N. Hasanah, N. Farhayu, M.W. Hussin, M.B.M. Tahir, J. Mirza, Properties of porous concrete 
from waste crushed concrete (recycled aggregate), Constr. Build. Mater. 47 (2013) 1243-1248. doi:10.1016/j.conbuildmat.2013.06.022.

[16] M. Gesoğlu, E. Güneyisi, G. Khoshnaw, S. Ipek, Investigating properties of pervious concretes containing waste tire rubbers, Constr. Build. Mater. 63 (2014) 206-213. doi:10.1016/j. conbuildmat.2014.04.046.

[17] G.F.B. Sandoval, I. Galobardes, R.S. Teixeira, B.M. Toralles, Case Studies in Construction Materials Comparison between the falling head and the constant head permeability tests to assess the permeability coe ffi cient of sustainable Pervious Concretes, Case Stud. Constr. Mater. 7 (2017) 317-328. doi:10.1016/j.cscm.2017.09.001.

[18] W. Yeih, T.C. Fu, J.J. Chang, R. Huang, Properties of pervious concrete made with air-cooling electric arc furnace slag as aggregates, Constr. Build. Mater. 93 (2015) 737-745. doi:10.1016/j.conbuildmat.2015.05.104.

[19] Instituto Aço Brasil, Relatório de Sustentabilidade 2014 - Sabesp, (2014) 246. doi:10.1017/CBO9781107415324.004.

[20] K. Ćosić, L. Korat, V. Ducman, I. Netinger, Influence of aggregate type and size on properties of pervious concrete, Constr. Build. Mater. 78 (2015) 69-76. doi:10.1016/j.conbuildmat.2014.12.073.

[21] UNE EN 1744-1, Ensayos para determinar las propiedades químicas de los áridos. Parte 1: Análisis químico., ([s.d.]).

[22] BASF, POZZOLITH 475 N, BASF Constr. Chem. España, S.L. (2010) 1-2.

[23] PROPAMSA, Propam emulsión $®, ~(2010)$ 102-103.

[24] N. Neithalath, J. Weiss, J. Olek, Characterizing Enhanced Porosity Concrete using electrical impedance to predict acoustic and hydraulic performance, Cem. Concr. Res. 36 (2006) 2074-2085. doi:10.1016/j.cemconres.2006.09.001.

[25] J.T. Kevern, V.R. Schaefer, K. Wang, Predicting Performance of Pervious Concrete using Fresh Unit Weight J.T. Kevern 1 ,V.R. Schaefer 2 , and K. Wang 3 1, (2009).

[26] A.K. Chandrappa, K.P. Biligiri, Comprehensive investigation of permeability characteristics of pervious concrete: A hydrodynamic approach, Constr. Build. Mater. 123 (2016) 627-637. doi:10.1016/j.conbuildmat.2016.07.035.

[27] American Concrete Institute (ACl), Report On Pervious Concrete (ACI 522-R10), 2010.

[28] W.D. Martin, N.B. Kaye, B.J. Putman, Impact of vertical porosity distribution on the permeability of pervious concrete, Constr. Build. Mater. 59 (2014) 78-84. doi:10.1016/j.conbuildmat.2014.02.034.

[29] R. Pieralisi, S.H.P. Cavalaro, A. Aguado, Advanced numerical assessment of the permeability of pervious concrete, Cem. Concr. Res. 102 (2017) 149-160. doi:10.1016/j.cemconres.2017.09.009.

[30] K.H. Fwa, T.F.;Lim Emiko; Tan, Comparison of Permeability and Clogging Characteristics of Porous Asphalt and Pervious Concrete Pavement Materials, (2014).

[31] A. Kia, H.S. Wong, C.R. Cheeseman, Clogging in permeable concrete: A review, J. Environ. Manage. 193 (2017) 221-233. doi:10.1016/j.jenvman.2017.02.018.

[32] C. Gaedicke, A. Marines, F. Miankodila, A method for comparing cores and cast cylinders in virgin and recycled aggregate pervious concrete, Constr. Build. Mater. 52 (2014) 494-503. doi:10.1016/j.conbuildmat.2013.11.043.

[33] B.J. Putman, A.I. Neptune, Comparison of test specimen preparation techniques for pervious concrete pavements, Constr. Build. Mater. 25 (2011) 3480-3485. doi:10.1016/j. conbuildmat.2011.03.039.

[34] A.I. Neptune, B.J. Putman, Effect of Aggregate Size and Gradation on Pervious Concrete Mixtures, ACl Mater. J. (2010). 